\title{
Hubungan Komunikasi Terapeutik dan Risiko Perilaku Kekerasan pada Pasien Skizofrenia di Rumah Sakit Jiwa Provinsi Bali
}

\author{
I Dewa Gd Putra Jatmika ${ }^{1}$, Komang Yogi Triana ${ }^{2 *}$, Ni Komang Purwaningsih ${ }^{3}$ \\ ${ }^{1,2,3}$ Program Studi S1 Keperawatan, STIKES Bina Usada, Bali, Indonesia \\ *yogitriana25@gmail.com
}

\begin{abstract}
Violent behavior is one of symptoms that can be demonstrated by patients with schizophrenia which it can cause injury to the patient and others. Therapeutic communication is one of the nursing intervention for patients with violent behavior. This study aimed to identify the relationship of communication and risk of violent behavior in schizophrenic patients. This study used a descriptive correlational with a cross-sectional design, which involved 68 patients with schizophrenia who were selected by consecutive sampling technique. The instrument in this study used a therapeutic communication checklist and observation sheets for changes in violent behavior. The results showed that as many as 35 patients (51.5\%) who received good therapeutic communication from nurses, and 37 (54.4\%) patients showed moderate risk of violent behavior. The results of the analysis by the Gamma ordinal by ordinal test found that there was a significant relationship between therapeutic communication and the risk of violent behavior with $p$ value $=0.001(<0.05)$. It showed that the better therapeutic communication applied, the lower of the incidence of violent behavior in schizophrenic patients. Thus it is expected that nurses can practice therapeutic communication techniques to improve the patient's condition so that violent behavior in patients can be reduced.
\end{abstract}

Keywords: therapeutic communication, violent behavior, schizophrenia

\begin{abstract}
Abstrak
Perilaku kekerasan sebagai bentuk perilaku yang dapat ditunjukkan oleh pasien dengan skizofrenia. Perilaku ini dapat menyebabkan cedera terhadap diri pasien maupun orang lain disekitarnya. Komunikasi terapeutik yang diterapkan oleh perawat menjadi salah satu pilihan intervensi bagi pasien dengan perilaku kekerasan. Penelitian ini bertujuan untuk mengidentifikasi hubungan komunikasi dan risiko perilaku kekerasan pada pasien skizofrenia. Penelitian ini menggunakan desain deskriptif korelasional dengan rancangan cross-sectional, yang melibatkan 68 pasien dengan skizofrenia yang dipilih dengan teknik consecutive sampling. Instrumen pada penelitian ini menggunakan checklist komunikasi terapeutik dan lembar observasi perubahan perilaku kekerasan. Hasil penelitian menunjukkan bahwa sebanyak 35 orang pasien $(51,5 \%)$ menerima komunikasi terapeutik yang cukup baik dari perawat, dan sebagian sebanyak 37 orang $(54,4 \%)$ menunjukkan risiko perilaku kekerasan kategori sedang. Hasil analisis dengan uji ordinal by ordinal Gamma mendapatkan hasil bahwa ada hubungan signifikan antara komunikasi terapeutik dengan risiko perilaku kekerasan dengan nilai $\mathrm{p}=$ 0,001 (nilai $\mathrm{p}<0,05$ ). Hal ini menunjukkan semakin baik komunikasi terapeutik yang dilakukan perawat, maka semakin rendah kejadian perilaku kekerasan pada pasien skizofrenia. Dengan demikian diharapkan perawat dapat melatih teknik komunikasi terapeutik dan mengembangkan intervensi keperawatan lainnya untuk perbaikan kondisi pasien sehingga perilaku kekerasan pada pasien dapat berkurang.
\end{abstract}

Kata Kunci: komunikasi terapeutik, perilaku kekerasan, skizofrenia 


\section{PENDAHULUAN}

Pada zaman digital dan era globalisasi seperti sekarang ini, orang dengan gangguan kesehatan jiwa jumlahnya cenderung mengalami peningkatan. WHO (2016) mengungkapkan data bahwa sebanyak 35 juta orang dikatakan mengidap depresi, 60 juta orang lainnya terkena bipolar, skizofrenia sebanyak 21 juta orang, dan sebanyak 47,5 juta orang terkena dimensia. Di Indonesia, kondisi pasien dengan skizofrenia sudah mencapai 1,7 per mil yang berarti terdapat satu sampai dua penduduk yang menderita skizofrenia dari 1000 penduduk Indonesia (Riset Kesehatan Dasar [Riskesdas], 2013). Data dari Departemen Kesehatan Republik Indonesia (Depkes RI) tahun 2013, Provinsi Bali berada di peringkat ketiga kasus gangguan jiwa terbanyak setelah Provinsi Yogyakarta dan Aceh dengan prevalensi 2,3 per mil. Sedangkan, di Provinsi Bali pada tahun 2014 diperkirakan sebanyak 3\% dari 4 juta jumlah penduduk atau sekitar 120.000 orang penduduk Bali mengalami gangguan jiwa, dimana 7000-8000 orang diantaranya mengalami gangguan jiwa yang tergolong berat. Angka ini mengalami peningkatan pada tahun 2018, dimana Bali telah menduduki peringkat pertama di Indonesia sebagai provinsi dengan pasien skizofrenia terbanyak yaitu mencapai 11 permil (Kemenkes, 2018).

Berdasarkan Rekam Medik Rumah Sakit Jiwa Propinsi Bali (2019) dan studi pendahuluan yang dilakukan di ruang Intensive Psychiatric Care Unit (IPCU) Unit Pelayanan Terpadu Daerah (UPTD) Rumah Sakit Jiwa (RSJ) Provinsi Bali, jumlah pasien yang dirawat dari bulan Januari sampai Maret mengalami fluktuasi. Pada bulan Januari 2019 dari 130 pasien yang dirawat, jumlah pasien dengan skizofrenia sebanyak 81 orang, dengan risiko perilaku kekerasan sebanyak 71 orang. Pada bulan Februari 2019 jumlah pasien yang dirawat sebanyak 131 orang dengan skizofrenia sebanyak 84 orang dengan risiko perilaku kekerasan sebanyak 73 orang, sedangkan pada bulan Maret 2019 jumlah pasien yang di rawat di ruang IPCU sebanyak 212 orang dengan jumlah pasien skizorenia sebanyak 84 orang dan mengalami perilaku kekerasan sebanyak 75 orang. Berdasarkan dari jumlah pasien skizorenia yang dirawat, hal ini tampak mengalami fluktuasi tetapi jumlah pasien yang mengalami perilaku maupun risiko perilaku kekerasan ada kecenderungan terjadi peningkatan.

Banyak hal dapat menjadi faktor-faktor pemicu yang menimbulkan stres dan meningkatkan risiko menderita gangguan jiwa seperti kehilangan orang yang dicintai, kegagalan dalam hidup, masalah dalam pernikahan, putusnya hubungan sosial, tekanan dalam pekerjaan dan krisis ekonomi (Sari, 2015). Selain itu ada empat masalah kesehatan utama yang terjadi di kalangan masyarakat, antara lain kanker, penyakit degeneratif, gangguan jiwa dan kecelakaan. Walaupun gangguan jiwa sering kali tidak dianggap sebagai gangguan yang dapat menyebabkan kematian langsung terhadap seseorang, akan tetapi beratnya kondisi dari gangguan yang dialami seseorang tersebut dikhawatirkan akan menghambat pembangunan, karena dianggap tidak efisien dan tidak produktif serta sering menyebabkan terjadinya perilaku amuk (perilaku kekerasan) dari orang dengan gangguan jiwa yang menjadi suatu ketakutan dari keluarga dan masyarakat. 
Perilaku kekerasan (PK) didefinisikan sebagai rentang emosi yang berupa ungkapan kemarahan seseorang, ditunjukkan secara verbal maupun fisik terhadap lingkungan sekitarnya (Direja, 2011). Perilaku kekerasan dalam bentuk verbal sebagai suatu aksi yang agresif dari seseorang yang diungkapkan dalam bentuk kata-kata yang kotor, umpatan, serta ejekan dan berbicara dengan nada keras, serta ancaman melalui kata-kata yang menyakiti perasaan lawan bicara (Keliat dkk, 2011). Selain itu, perilaku kekerasan juga dapat berupa aksi fisik yang ditunjukkan dengan tindakan memukul, mengancam orang lain dengan senjata, menendang, dan menyerang orang lain.

Kondisi ini tidak dapat dibiarkan dan harus ditangani dengan segera, karena perilaku tersebut mengakibatkan cedera baik untuk diri pasien sendiri maupun orang lain, bahkan dapat berujung pada kematian (Viedeback, 2008). Menurut Beck, Rawlins \& William (1986) dalam Keliat dkk (2011) menyebutkan bahwa respon penyebab marah yang dapat menyebabkan terjadinya perilaku kekerasan dapat ditekan dan dikontrol dengan tiga cara yaitu dengan mengungkapkan secara verbal, menekan pasien dan menantang pasien. Dari ketiga cara tersebut cara pertama merupakan cara konstruktif dan cara kedua dan ketiga adalah cara destruktif. Cara konstruktif merupakan pilihan yang tepat untuk pasien dengan perilaku kekerasan. Agar dapat melakukan cara konstruktif tersebut dibutuhkan keahlian perawat dalam melakukan komunikasi yang bersifat terapeutik dalam perawatan pasien dengan berisiko perilaku kekerasan.
Komunikasi terapeutik dikenal sebagai hubungan interpersonal yang terjadi antara 2 pihak, yaitu perawat sebagai pemberi asuhan klien dengan kliennya. Perawat dan kliennya dikatakan memperoleh pengalaman belajar bersama untuk meningkatkan dan memperbaiki pengalaman emosional dari klien. Kemampuan perawat sebagai tenaga kesehatan dalam melakukan komunikasi terapeutik yang baik dan benar dapat mencegah tindakan agresif/ perilaku kekerasan pasien dan menunda untuk dilakukannya restrain dan tindakan isolasi pasien. Penerapan komunikasi yang baik oleh tenaga kesehatan terhadap pasien menjadi kemampuan yang penting dimiliki oleh tenaga kesehatan (Purwaningsih dan Dewi, 2019). Namun pada kenyataannya, tidak semua tenaga kesehatan mampu menerapkan teknik komunikasi terapeutik yang tepat kepada pasien maupun keluarga. Perawat jiwa memiliki peran penting dalam mencegah terjadinya perilaku kekerasan sehingga pasien dapat tetap tenang. Namun, belum diketahui pasti apakah penerapan komunikasi terapeutik perawat terkait dengan risiko munculnya perilaku kekerasan pada pasien dengan skizofrenia. Penelitian ini bertujuan untuk mengetahui hubungan komunikasi terapeutik perawat terhadap risiko munculnya perilaku kekerasan pada pasien dengan skizofrenia di IPCU UPTD RSJ Provinsi Bali.

\section{METODE}

Penelitian ini menggunakan desain deskriptif korelasional dengan rancangan Cross-Sectional. Sebanyak 68 responden yang merupakan klien skizofrenia yang dirawat di Ruang IPCU (Intensive Psychiatric Care Unit) dilibatkan dalam penelitian ini yang dipilih dengan teknik 
Consecutive Sampling. Peneliti didampingi oleh enumerator dalam mengisi kuesioner untuk mengidentifikasi komunikasi terapeutik yang diterapkan perawat kepada responden yang dalam hal ini adalah klien skizofrenia. Selanjutnya, enumerator juga mengidentifikasi perubahan perlikau kekerasan yang ditunjukkan oleh klien. Hal ini dilakukan, dengan mempertimbangkan klien yang mengalami gangguan secara kognitif. Peneliti menggunakan checklist penilaian komunikasi terapeutik yang merupakan SPO (Standar Prosedur Operasional) yang telah diterapkan di RSJ Provinsi Bali dan lembar observasi perubahan perilaku kekerasan oleh Stuart (2013) sebagai instrumen dalam penelitian ini. Data yang diperoleh, selanjutnya dianalisis dengan uji ordinal by ordinal Gamma. Penelitian dilakukan selama 1 bulan yaitu pada bulan November tahun 2019 di Rumah Sakit Jiwa Provinsi Bali dan telah dinyatakan laik etik dengan nomor No. 471/EA/KEPK-BUB-2019.
HASIL

Tabel 1. Karakteristik Klien Skizofrenia dengan Perilaku Kekerasan di Ruang IPCU UPTD RSJ Provinsi Bali tahun 2019 $(\mathbf{n}=68)$

\begin{tabular}{llcc}
\hline Karakteristik & & Jumlah & $\%$ \\
\hline Usia & 17-25 Tahun & 8 & 11,8 \\
& 26-35 Tahun & 21 & 30,9 \\
& 36-45 Tahun & 19 & 27,9 \\
& 46-55 Tahun & 13 & 19,1 \\
& 56-65 Tahun & 6 & 8,8 \\
& $>$ 65 Tahun & 1 & 1,5 \\
\hline Status & Kawin & 33 & 48,5 \\
Perkawinan & & & \\
& Tidak Kawin & 35 & 51,5 \\
\hline Jenis & Laki-laki & 38 & 55,9 \\
Kelamin & Perempuan & 30 & 44,1 \\
\hline Tingkat & Tidak & 26 & 38.2 \\
pendidikan & Sekolah & & \\
& Sekolah & 20 & 29.4 \\
& Dasar (SD) & & \\
& Sekolah & & \\
& Menengah & 12 & 17.6 \\
& Pertama & & \\
& (SMP) & & \\
& Sekolah & & \\
& Menengah & 8 & 11.8 \\
& Atas (SMA) & & \\
& Diploma & 1 & 1.5 \\
& Sarjana & 1 & 1.5 \\
\hline & & &
\end{tabular}

Berdasarkan tabel 1 yang membahas tentang karakteristik responden, dapat dilihat bahwa hasil penelitian menunjukkan dari total responden sebanyak 68 orang, didapatkan responden terbanyak pada umur 26-35 tahun sebesar 30,9\%, selain itu dilihat dari segi status perkawinan, sebagian besar responden tidak menikah (kawin) yaitu sebanyak 35 orang atau sebesar $51,5 \%$. Jenis kelamin laki-laki mendominasi klien yang dilibatkan dalam penelitian ini, yaitu sebanyak 38 orang atau sebesar 55,9\%, dan dilihat dari segi tingkat pendidikan, klien skizofrenia sebagian besar tidak sekolah yaitu sebanyak 26 orang $(38,2 \%)$ 
Tabel 2. Hasil Analisis Deskriptif Variabel Komunikasi Terapeutik Perawat di IPCU UPTD RSJ Provinsi Bali tahun $2019(n=68)$

\begin{tabular}{lcc}
\hline $\begin{array}{l}\text { Komunikasi } \\
\text { terapeutik }\end{array}$ & Jumlah & $\begin{array}{c}\text { Persentase } \\
(\%)\end{array}$ \\
\hline Baik & 14 & 20.6 \\
Cukup & 35 & 51.5 \\
Kurang & 19 & 27.9 \\
\hline
\end{tabular}

Klien dalam penelitian ini sebagian besar menerima komunikasi terapeutik dengan katagori cukup oleh perawat yang bertugas yaitu sebanyak 35 klien atau sebesar 51,5\%.

Tabel 3. Hasil Analisis Deskriptif Variabel Risiko Perilaku Kekerasan pada Pasien Skizofrenia di IPCU UPTD RSJ Provinsi Bali tahun $2019(n=68)$

\begin{tabular}{lcc}
\hline $\begin{array}{l}\text { Risiko Perilaku } \\
\text { Kekerasan }\end{array}$ & Jumlah & $\begin{array}{c}\text { Persentase } \\
(\%)\end{array}$ \\
\hline Tinggi & 23 & 33.8 \\
Sedang & 37 & 54.4 \\
Rendah & 8 & 11.8 \\
\hline
\end{tabular}

Responden dalam penelitian ini menunjukkan risiko perilaku kekerasan paling banyak pada katagori sedang yaitu sebanyak 37 orang atau sebesar 54,4\%. Sisanya berada pada katagori tinggi dan rendah masing-masing sebanyak 23 orang $(33,8 \%)$ dan delapan orang $(11,8 \%)$.

Tabel 4. Hasil Uji Statistik Gamma Hubungan Komunikasi Terapeutik Perawat dengan Risiko Perilaku Kekerasan pada Pasien Skizof renia di IPCU UPTD RSJ Provinsi Bali tahun 2019 $(n=68)$

\begin{tabular}{lcccccc}
\hline Komuni- & \multicolumn{2}{c}{ Perilaku kekerasan } & Total & \multicolumn{2}{c}{ P value } \\
\cline { 2 - 6 } $\begin{array}{l}\text { kasi } \\
\text { Terapeu- } \\
\text { tik }\end{array}$ & Tinggi & Sedang & Rendah & & $\begin{array}{l}\text { Correlati- } \\
\text { on Coef. }\end{array}$ \\
\cline { 2 - 6 } & $\mathrm{f}$ & $\mathrm{f}$ & $\mathrm{f}$ & $\mathrm{f}$ & & \\
\hline Baik & 0 & 6 & 8 & 14 & 0,001 & $-0,936$ \\
Cukup & 8 & 27 & 0 & 35 & & \\
kurang & 15 & 4 & 0 & 19 & & \\
\hline Total & 23 & 37 & 8 & 68 & &
\end{tabular}

Berdasarkan analisis data yang telah dilakukan menunjukkan bahwa hubungan komunikasi terapeutik perawat dengan risiko perilaku kekerasan pada pasien skizofrenia menghasilkan nilai $\mathrm{p}=0,001(\mathrm{p}$ value $<\alpha$ ), maka hipotesis penelitian $(\mathrm{Ha})$ diterima yang berarti ada hubungan komunikasi terapeutik perawat dengan risiko perilaku kekerasan pada pasien skizofrenia di IPCU UPTD RSJ Provinsi Bali.

\section{PEMBAHASAN}

Pada penelitian ini didapatkan responden terbanyak berada pada rentang umur 26-35 tahun yang tergolong dalam usia produktif. Hal ini sejalan dengan penelitian Maramis (2009) yang mengungkapkan bahwa dari jenis-jenis skizofrenia yang ada, sebagian besar berada pada usia produktif antara umur 15-30 tahun. Kaplan dan Sadock (2010) juga mengungkapkan bahwa antara pria dan wanita memiliki onset usia terjadinya skizofrenia berbeda, dimana laki-laki cenderung mengalami skizofrenia pada usia 15-25 tahun, sedangkan puncak usia pada wanita adalah pada usia 25-35 tahun (Wijayanti dan Puspitosari, 2014). Karakteristik umur seseorang dikatakan menunjukkan ada hubungan dengan pengalaman dari seseorang dalam memanfaatkan sumber, dukungan menghadapi berbagai stresor, serta dukungan dan keterampilan dalam mekanisme koping terhadap suatu masalah (Stuart, 2013).

Menurut Maramis (2009) pasien gangguan jiwa sebagian besar ditemukan pada orang yang berstatus sudah kawin karena pada status tersebut seorang sudah memasuki fase lebih lanjut dalam hidupnya dan akan memiliki beban hidup tambahan yaitu 
beban kebutuhan rumah tangga. Tetapi pada penelitian ini didapatkan responden terbanyak belum menikah, hal tersebut dikarenakan kondisi responden yang sudah menderita gangguan jiwa sejak usia muda. Hal ini sejalan dengan penelitian Melas, Tartani, Forsner, Edhborg, dan Forsell (2013) di Swedia, yang menyatakan bahwa sebagian besar remaja yang berusia rata-rata 16 tahun, mengalami depresi dan skizofrenia. Hal ini tidak terlepas dari adanya stigma-stigma yang didapatkan oleh remaja dari lingkungannya (Melas dkk., 2013). Selain itu dukungan dari keluarga serta lingkungan dengan stigmanya yang kurang baik tentang orang dengan gangguan jiwa menyebabkan pasien dengan gangguan jiwa sulit untuk mendapatkan pasangan hidup.

Penelitian ini juga menunjukkan sebanyak $55,9 \%$ responden berjenis kelamin laki-laki yang berarti pasien laki-laki lebih banyak dibandingkan perempuan. Hal ini sesuai dengan hasil Riskesdas (2013) yang menyatakan bahwa penderita gangguan jiwa kategori berat lebih banyak dialami oleh kaum laki-laki dibandingkan perempuan. Laki-laki memiliki perbedaan dalam banyak hal dibandingkan perempuan, termasuk dari segi kebiasaan, pengaruh lingkungan, dan hubungan sosial dalam kehidupan sehari-hari yang dapat memicu terjadinya gangguan jiwa. Dari karakteristik jenis kelamin, gangguan jiwa dengan jenis skizofrenia pada laki-laki menunjukkan angkat tiga kali lebih tinggi dibandingkan yang dialami wanita. Kondisi ini berhubungan erat dengan tanggungan tuntutan hidup laki-laki yang dituntut sebagai pencari nafkah atau tulang punggung dalam keluarga sehingga lakilaki dituntut untuk dapat bekerja keras sementara lapangan pekerjaan masih terbatas (Keliat, 2011).

Pendidikan menjadi salah satu tolak ukur dari kemampuan seseorang untuk dapat saling berinteraksi dengan efektif. Keterlibatan pasien dalam proses belajar secara tidak langsung dipengaruhi oleh kemauan pasien untuk memperoleh pengetahuan yang lebih (Stuart, 2013). Namun, pasien skizofrenia dalam penelitian ini sebanyak 26 orang dengan latar belakang tidak bersekolah. Hal ini dapat disebabkan oleh adanya stigma di masyarakat mengenai pasien dengan skizofrenia dan keterbatasan kemampuan pasien dalam menerima pelajaran dan kemampuan bersosialisasi dengan lingkungan. Dengan demikian, keluarga memilih untuk tidak melanjutkan pendidikan pasien.

Pada penelitian ini sebagian besar klien dengan skizofrenia menerima komunikasi terapeutik yang diberikan oleh perawat dengan kategori cukup yaitu sebanyak 35 orang. Hal ini berarti perawat di lokasi penelitian sudah berupaya menerapkan komunikasi terapeutik dengan cukup baik terhadap sebagian besar klien dengan skizofrenia. Terdapat beberapa faktor yang mempengaruhi penerapan komunikasi terapeutik oleh perawat, antara lain faktor emosi, faktor lingkungan, faktor jarak, dan faktor bahasa (Ananda, 2018). Hasil penelitian ini juga sesuai dengan teori yang dinyatakan oleh Stuart (2013) mengenai komunikasi terapeutik yang dikatakan sebagai hubungan interpersonal antara perawat sebagai caregiver terhadap kliennya, sehingga perawat maupun klien memperoleh pengalaman belajar bersama untuk memperbaiki pengalaman emosional yang dirasakan klien sehingga tercipta 
hubungan terapeutik. Kondisi pasien sangat mempengaruhi keberhasilan komunikasi terapeutik yang dilakukan oleh tenaga kesehatan dalam hal ini perawat. Kondisi pasien yang masih labil dengan tingkat emosional yang cukup tinggi akan sangat sulit untuk diajak berinteraksi secara verbal. Selain itu tingkat pendidikan responden yang cukup rendah juga mempengaruhi keberhasilan komunikasi terapeutik yang diterapkan oleh perawat.

Berdasarkan teknik dan prosedur komunikasi terapeutik yang dilakukan perawat, komunikasi pada tahap orientasi yang masih sering dilupakan untuk dilakukan sehingga pasien masih merasa asing dengan perawat, akan tetapi perawat sudah memberikan tindakan terhadap responden yang sekaligus sebagai pasien dalam penelitian ini. Keterampilan dari perawat untuk mengolah kata-kata dalam menghadapi pasien dengan perilaku kekerasan berbeda-beda. Perawat dalam penelitian ini dinilai cukup mampu menerapkan komunikasi terapeutik sesuai dengan teori yang dikemukakan oleh Roselina (2009) mengenai lima sikap untuk dapat menghadirkan diri secara fisik yang dapat memfasilitasi terwujudnya komunikasi terapeutik, antara lain mempertahankan kontak mata, memperlihatkan sikap terbuka, berhadapan, membungkuk kearah klien, dan tetap rileks.

Sebagian besar responden dalam penelitian ini menunjukkan risiko perilaku kekerasan pada kategori sedang. Hal ini sesuai dengan teori dari Direja (2011) yang menyatakan bahwa perilaku kekerasan itu sendiri menunjukkan beberapa tanda diantaranya dapat dilihat secara fisik yaitu dari perilaku pasien yang menunjukkan mata terlihat melotot dan pandangan tajam, tangan dikepalkan kuat, rahang dikatupkan, wajah terlihat semakin merah dan tegang, tubuh menjadi kaku, menyerang orang sekitarnya, melukai diri sendiri atau orang lain, mengamuk dan merusak lingkungan sekitarnya. Perilaku kekerasan juga dapat ditunjukkan secara verbal kepada orang lain, hal ini terlihat dari keluarnya umpatan, kata-kata kotor, ancaman, berbicara dengan nada keras, kasar dan ketus dari mulut seseorang. Dilihat dari segi emosi dan intelektual, perilaku kekerasan dapat berupa perasaan yang perasaan tidak aman dan tidak nyaman yang dirasakan seseorang, mengamuk, mendominasi, merasa terganggu, bermusuhan, kesal dan dendam, merasa tidak berdaya, ingin berkelahi, menyalahkan dan menuntut, banyak bicara, bersikap kasar, dan suka berdebat. Lalu jika ditinjau secara spiritual dan sosial dapat berupa keragu-raguan, perasaan selalu berkuasa, menarik diri, merasa diri selalu paling benar, keraguraguan, tidak bermoral, pengasingan, penolakan, kekerasan, kreativitas terhambat, munculnya ejekan dan sindiran (Direja, 2011).

Hasil analisis data dalam penelitian menunjukkan bahwa terdapat hubungan yang signifikan antara komunikasi terapeutik perawat terhadap risiko perilaku kekerasan pada pasien skizofrenia yang yang dirawat di IPCU UPTD RSJ Provinsi Bali. Hal tersebut sesuai dengan teori yang dikemukakan oleh Suryani (2005) yang menyatakan bahwa seorang perawat atau penolong dapat membantu klien dengan gangguan jiwa mengatasi masalah yang dihadapinya melalui teknik komunikasi yang tepat. Komunikasi terapeutik yang dilakukan oleh perawat sangat mempengaruhi kondisi pasien dengan 
perilaku kekerasan. Komunikasi terapeutik yang dilakukan dengan baik dalam menghadapi kondisi pasien perilaku kekerasan dapat membantu pasien untuk membantu mengontrol perilakunya. Hal ini juga sesuai dengan penelitian yang dikemukakan oleh Witojo \& Widodo (2008) yang mendapatkan hasil bahwa ada pengaruh dari penerapan komunikasi terapeutik terhadap penurunan perilaku kekerasan dari pasien skizofrenia yang dirawat di RSJ. Purwaningsih dan Dewi (2019) juga mengungkapkan bahwa kemampuan dalam menerapkan komunikasi yang baik oleh tenaga kesehatan terhadap pasien, akan berdampak baik terhadap kualitas pelayanan kesehatan.

Hasil penelitian lainnya yang juga sejalan dengan penelitian ini dikemukakan oleh Mustika dan Khaerudin (2013) yang dilakukan dengan quasi experimental prepost test with control group design didapatkan hasil dengan penerapan komunikasi terapeutik yang baik terjadi penurunan risiko perilaku kekerasan yang lebih bermakna daripada dengan yang tidak diberikan intervensi dengan $\mathrm{p}$ value $<0.05$ dan ada hubungan keeratan yang sangat kuat $(r=0,936)$. Penelitian oleh Novendra (2019) juga menyarankan agar petugas kesehatan khususnya perawat dapat menerapkan komunikasi yang baik dalam menerapkan asuhan keperawatan jiwa terhadap pasien yang menunjukkan perilaku kekerasan yaitu pada penerapan SP (strategi pelaksanaan) 1 sampai dengan 4 sehinga kualitas pelayanan dapat ditingkatkan. Hal ini juga diungkapkan oleh Siti, Zulpahiyana, \& Indrayana (2016) yang menyatakan bahwa penerapan komunikasi terapeutik dapat meningkatkan kualitas pelayanan di RS.

\section{KESIMPULAN}

Berdasarkan pembahasan tersebut, maka dapat ditarik suatu kesimpulan bahwa komunikasi terapeutik memiliki hubungan yang sangat kuat dengan menurunnya risiko perilaku kekerasan pada pasien skizofrenia di IPCU RSJ Provinsi Bali (nilai $\mathrm{p}=0,001$ dan $\mathrm{r}=-0,936$ ), dimana semakin baik komunikasi yang diterapkan oleh perawat maka semakin rendah juga risiko munculnya perilaku kekerasan pada pasien skizofrenia.

Tenaga kesehatan dalam hal ini perawat khususnya perawat jiwa diharapkan dapat meningkatkan penerapan komunikasi terapeutik saat bertugas, sehingga dapat menurunkan risiko munculnya perilaku kekerasan pada pasien skizofrenia. Hal ini diharapkan akan berdampak pada kualitas perawatan yang diberikan dan kepuasan pasien serta keluarga pasien terhadap pelayanan di RSJ Provinsi Bali. Penelitian selanjutnya diharapkan dapat mempertimbangkan faktor-faktor lain yang mempengaruhi masing-masing variabel sehingga diharapkan akan mendapatkan hasil penelitian yang lebih baik dan bervariasi.

\section{DAFTAR PUSTAKA}

Ananda, G. D. (2018). Komunikasi terapeutik perawat terhadap pasien di rumah sakit jiwa aceh. Jurnal Ilmiah Mahasiswa Fakultas Ilmu Sosial \& Ilmu Politik, $3(2)$.

Depkes RI. (2013). Riset kesehatan dasar (National Health Survey). Ministry of Health Republic of Indonesia, (1), 1303. https://doi.org/10.1007/s13398014-0173-7.2 
Direja, A. H. . (2011). Buku ajar asuhan keperawatan jiwa. Yogyakarta: Nuha Medika.

Hidayat, A. (2010). Metode penelitian kesehatan paradigma kuantitatif. Jakarta.

Keliat, B. A., \& Dkk. (2011). Proses keperawatan kesehatan jiwa. Jakarta: EGC.https://doi.org/10.1016/j.jmii.201 5.03.004.

Kementerian Kesehatan Republik Indonesia. (2017). Peraturan menteri kesehatan republik indonesia nomor 54 tahun 2017 tentang penanggulangan pemasungan pada orang dengan gangguan jiwa. In Kementerian Kesehatan. https://doi.org/10.1111/j.14697610.2010.02280.x.

Kementerian Kesehatan Republik Indonesia Badan Penelitian dan Pengembangan Kesehatan. (2018). Hasil Utama Riskesdas 2018. Jakarta.

Maramis, W. F. (2009). Catatan ilmu kedokteran jiwa (edisi 2). Surabaya: Airlangga University Press.

Melas, P. A., Tartani, E., Forsner, T., Edhborg, M., \& Forsell, Y. (2013). Mental health literacy about depression and schizophrenia among adolescents in Sweden. European Psychiatry, 28(7), 404-411.

Mustika,I Nengah., \& Khaerudin. (2013). Efektifitas komunikasi terapeutik terhadap perilaku kekerasan pada pasien skizofrenia di rumah sakit marzoeki mahdi, Bogor. Politeknik Kemenkes Bandung.

Novendra, R. (2019). Pengelolaan keperawatan resiko perilaku kekerasan (rpk) pada tn. a dengan skizofrenia di wisma puntadewa rumah sakit jiwa prof. $d r$ soerojo magelang (Doctoral Dissertation, Universitas Ngudi Waluyo).

Purwaningsih, N. K., \& Dewi, S. P. A. A. P. (2019). The analysis of speech act in verbal communication between healthcare professionals and patients in public health centre branch kerobokan kelod. Journal of English Educational Study (JEES), 2(1), 11-20.

Rekam Medik Rumah Sakit Jiwa Propinsi Bali. (2019). Laporan tahunan rumah sakit jiwa provinsi bali. Bangli.

Riskesdas. (2013). Riset Kesehatan Dasar (Indonesian Basic Health Survey) 2013. Laporan Nasional 2013. https://doi.org/10.3406/arch.1977.1322.

Roselina. (2009). Buku saku komunikasi keperawatan. Jakarta: Trans Info Media.

Sari, Nina Permata, \& Istichomah. (2015). Pengaruh pendidikan kesehatan tentang perilaku kekerasan terhadap pengetahuan keluarga dalam merawat pasien di poli jiwa rsj soedjarwadi klaten iawa. 06.

Stuart, G, W. (2013). Prinsip dan praktek keperawatan dan kesehatan jiwa (Edisi Indo). Jakarta: Fakultas Keperawatan Indonesia.

Siti, M., Zulpahiyana, Z., \& Indrayana, S. (2016). Komunikasi terapeutik perawat berhubungan dengan kepuasan pasien. Jurnal Ners dan Kebidanan Indonesia, 4(1), 30-34.

Suryani. (2005). Komunikasi terapeutik: Teori dan praktik. Jakarta: EGC.

Viedebeck. (2008). Videbeck, S L. (2008). Buku ajar keperawatan jiwa. Jakarta: EGC.

WHO. (2012). Risk to mental health: An overview of vulnerabilities and risk factors. Genewa.

Wijayanti, A., \& Puspitosari, W. A. (2014). Hubungan onset usia dengan kualitas hidup penderita skizofrenia di wilayah kerja puskesmas kasihan ii bantul yogyakarta. Mutiara Medika: Jurnal Kedokteran dan Kesehatan, 14(1), 3945. 
Witojo, D., \& Widodo, A. (2008). Pengaruh komunikasi terapeutik terhadap penurunan perilaku kekerasan di rumah sakit sakit jiwa daerah surakarta. Keperawatan, 1(keperawatan jiwa), 16. 